\title{
Factors affecting Nurse Anxiety during COVID-19 pandemic
}

\author{
Sendy Ayu Mitra Uktutias ${ }^{\mathrm{a}, \mathrm{b}}$, Puryanti ${ }^{\mathrm{a}}$, Serlly Frida Drastyana ${ }^{\mathrm{a}}$, $^{*}$ \\ ndyayuuktutias@gmail.com
}

College of Health Sciences of Soetomo Hospital Foundation, Surabaya East Java, Indonesia ${ }^{\mathrm{a}}$

Postgraduate School, Universitas Airlangga ${ }^{b}$

\begin{abstract}
SARS-CoV-2 is a new type of coronavirus that has never been previously identified in humans. The increase in the number of cases took place quite quickly, and spread to various countries in a short time and caused the death of the COVID-19 pandemic. Nurses are at higher risk of contracting COVID-19 because they are in closer and longer contact with patients. This situation can have a negative impact on the mental health of nurses. Nurses on the guard Nurses become highly vulnerable to many work-related hazards and experience a tremendous amount of emotional stress. The purpose of this study was to identify the factors that influence nurses' anxiety during the COVID-19 pandemic through Systematic Review. This study uses a systematic review method that presents an evidence-based assessment of nurses' anxiety during the COVID-19 pandemic. This research was conducted by searching for articles in the database GoogleScholar, SagePub, ProQuest, and ScienceDirect. The keywords in this systematic review are "Emotion" and "Anxiety", and "COVID-19" and "Pandemic". The search was limited to English and data sources on articles published from 2020-2021. Systemtic review reports are written using the PRISMA checklist. The selection process for articles was carried out so that 13 articles were obtained. The factors that cause anxiety in nurses during the COVID19 pandemic are based on a review of articles in categories based on the most common factors, including: gender (female nurse), work unit (hospital or room), risk perception, age, marital status, years of service, workload, information and training, availability of PPE, and level of education. It is important to hold training programs related to COVID-19 for nurses, to build a positive image of nurses. Hospitals should expend more efforts to ensuresupplies of personal protective equipment.
\end{abstract}

\section{Introduction}

World Health Organization (WHO) declared March 11, 2020 a COVID-19 pandemic. Coronavirus Disease 2019 (COVID-19) is an infectious disease caused by Severe Acute Respiratory Syndrome Coronavirus 2 (SARS-CoV-2). SARS-CoV-2 is a new type of coronavirus that has never been previously identified in humans. The increase in the number of cases took place quite quickly, and spread to various countries in a short time and caused deaths The COVID-19 pandemic had a negative impact on the mental health of health workers. Health workers, especially nurses, are at high risk of infection because they are in close proximity to patients (Y. Zhang et al., 2020).

Nurses are becoming health workers who are facing more psychological problems due to the 
COVID-19 outbreak (SK Ali, Shah, \& Talib, 2021). It was also shown that nurses are at higher risk of contracting COVID-19 because they are in closer and longer contact with patients. This situation can have a negative impact on the mental health of nurses (Cho et al., 2021). Nurses are on the guard Nurses become very vulnerable to many work-related hazards and experience a great amount of emotional stress in relation to jobdesk work (Aliet al., 2021).

A study was conducted on health workers in hospitals in South Korea, the results showed that nurses had more worries and also felt more nervous and anxious while in the ward when caring for patients than other health workers (Cai et al., 2020). As many as $25 \%$ of nurses experience anxiety when caring for COVID-19 patients (Salari et al., 2020). Meanwhile, research conducted on nurses in Ethiopia stated that the prevalence of anxiety was 66.9\% (Mekonen, Enyew; Shetie, Belayneh; Mukuneh, 2020). If this situation continues, nurses' mental health problems arise that affect the nurses' attention, understanding, and ability to make decisions. The food-term effect that occurs will affect the overall well-being of medical personnel (J. Zhang, Wu, Zhao, \& Zhang, 2019). Due to the health crisis caused by COVID-19, nurses have been exposed to stressful and uncertain situations, in such situations emotional coping strategies are very important because of their impact on health (Molero-Jurado, PérezFuentes, Gázquez-Linares, \& Santillan García, 2021). Nursing workers are one of the health workers who play an important role in improving health status and are the backbone of service facilities because they are more numerous than other health workers. In general, nurses have a very important role both in terms of promotive, preventive, and nursing care services in conditions of the COVID-19 outbreak. Since this situation can negatively affect nurses' mental health, the purpose of this study is to identify the factors that influence nurses' anxiety during the COVID-19 pandemic through Systematic Review.

\section{Methode}

This study uses a systematic review method that presents an evidence-based assessment of nurses' anxiety during the COVID-19 pandemic. This research was conducted by searching for articles in the databaseGoogleScholar, SagePub, ProQuest, and ScienceDirect. Article searches were carried out using keywords and Boolean operators (AND, OR NOT or AND NOT) to specify the search, so as to get articles that match the purpose of this research. keywords in this systematic review are adjusted to the Medical Subject Heading (MeSH) namely "Emotion" and "Anxiety", and "COVID-19" and "Pandemic". The search was limited to English and data sources on articles published from 2020-2021. The systematic review report is written using the checklist guide from PRISMA. The quality of the STUDY used in this study was obtained through a search strategy using the PICOS framework method.The selection process for articles was carried out by deleting one of the articles with the same title, leaving 68 articles. Screening based on title and abstract obtained as many as 55 articles. A total of 25 articles were then selected according to service criteria by considering the language of the article, the focus of the discussion, and the respondents involved. Articles were excluded from research that did not discuss anxiety factors and nurses, so that 13 articles were obtained.

\section{Result}

Based on 13 articles, it shows that anxiety is mostly measured by Generalized Anxiety Disorder-7 (GAD-7; Hospital Anxiety Depression Scale - Anxiety (HADS-A); Self-rating Anxiety Scale (SAS); Depression, Anxiety, and Stress Scale - 21 Items (DASS-21). Factors that affect nurses' anxiety during the COVID-19 pandemic based on Roy's Adaptation Theory model include focal stimulus (i.e. negative stigma from society or the 
surrounding environment ( 0 articles)), contextual stimulus (ie age (4 articles), gender (5 articles). ), marital status (3 articles), years of service ( 3 articles), education level ( 1 article), workspace unit (5 articles), availability of PPE (2 articles) and workload ( 3 articles) and residual stimulus (ie perception risk ( 5 articles) and information and training (3 articles)).

Table 1. Description of Results Literature Review

\begin{tabular}{|c|c|c|c|c|c|}
\hline No. & $\begin{array}{c}\text { Researcher, } \\
\text { Year, Country }\end{array}$ & Research Title & $\begin{array}{l}\text { Design } \\
\text { Study }\end{array}$ & $\begin{array}{c}\text { Research } \\
\text { Subject }\end{array}$ & Research result \\
\hline 1. & $\begin{array}{l}\text { Valentina Simonetti, } \\
\text { et al; } 2021 \text {; Italy }\end{array}$ & $\begin{array}{l}\text { Anxiety, sleep disorders, } \\
\text { and self-efficacy among } \\
\text { nurses during COVID-19 } \\
\text { pandemic: A large cross- } \\
\text { sectional study }\end{array}$ & $\begin{array}{l}\text { Quantitative; } \\
\text { Cross- } \\
\text { Sectional } \\
\text { Study. }\end{array}$ & Nurse $(n=131)$ & $\begin{array}{l}\text { The results showed that the level of } \\
\text { anxiety was higher among clinical } \\
\text { nurses who worked in general and } \\
\text { emergency hospital wards. Nurses' } \\
\text { anxiety levels were also higher } \\
\text { among those with more than two } \\
\text { children. }\end{array}$ \\
\hline 2. & $\begin{array}{l}\text { Mijung, Cho et al; } \\
\text { 2021; Korea selatan }\end{array}$ & $\begin{array}{l}\text { Factors affecting frontliner } \\
\text { Korean nurses' mental } \\
\text { health during the COVID- } \\
19 \text { pandemic }\end{array}$ & $\begin{array}{l}\text { Quantitative; } \\
\text { Cross- } \\
\text { Sectional } \\
\text { Study. }\end{array}$ & $\begin{array}{l}\text { Nurse } \\
(n=20613)\end{array}$ & $\begin{array}{l}\text { Factors that influence worry is } \\
\text { status marriage, work experience } \\
\text { of more than } 3 \text { months, and } \\
\text { hospital safety climate. }\end{array}$ \\
\hline 3. & $\begin{array}{l}\text { Indri Lestari; 2021; } \\
\text { Indonesia }\end{array}$ & $\begin{array}{lcr}\text { Analysis } & \text { of } & \text { Factors } \\
\text { Affecting } & \text { Nurse } & \text { Anxiety } \\
\text { During } & \text { Pandemic } & \text { COVID- } \\
19 & & \end{array}$ & $\begin{array}{l}\text { Quantitative; } \\
\text { Cross- } \\
\text { Sectional } \\
\text { Study. }\end{array}$ & Nurse $(n=55)$ & $\begin{array}{l}\text { The results showed that factor } \\
\text { which affect the level of anxiety } \\
\text { nurse during pandemi COVID-19 } \\
\text { of them information and Training, } \\
\text { workload. And risk perception } \\
\text { with nurse anxiety levels during the } \\
\text { Covid-19pandemic. }\end{array}$ \\
\hline 4. & $\begin{array}{l}\text { Su Hong et al; 2020; } \\
\text { China }\end{array}$ & $\begin{array}{l}\text { Immediate } r \text { psychological } \\
\text { impact on nurses working } \\
\text { at } 42 \text { government- } \\
\text { designated hospitals during } \\
\text { COVID-19 outbreak in } \\
\text { China: A cross-sectional } \\
\text { study }\end{array}$ & $\begin{array}{l}\text { Quantitative; } \\
\text { Cross-sectional }\end{array}$ & Nurse $(n=4692)$ & $\begin{array}{l}\text { The results showed a common risk } \\
\text { factor for anxiety was a lower level } \\
\text { ofeducation. }\end{array}$ \\
\hline 5. & $\begin{array}{l}\text { Shaimaa Ahmed } \\
\text { Awad Ali et al; } \\
\text { 2021; Saudia Arabia }\end{array}$ & $\begin{array}{l}\text { Exploring } r \\
\text { Psychological the } \\
\text { Anxiety Factors, and } \\
\text { Coping Mechanisms of } \\
\text { Critical Care Unit Nurses } \\
\text { During the COVID-19 } \\
\text { Outbreak in Saudia Arabia }\end{array}$ & $\begin{array}{l}\text { Quantitative } \\
\text { Cross-sectional }\end{array}$ & $\begin{array}{l}\text { Home Nurse } \\
\text { Pain }(n=469)\end{array}$ & $\begin{array}{l}\text { The results showed that more than } \\
\text { a third and a quarter of nurses } \\
\text { which researched to have level } \\
\text { severe and moderat anxiety. Most } \\
\text { factor causing worry is the } \\
\text { moment give maintenance for } \\
\text { colleagues nurse who is infected } \\
\text { and is concerned about } \\
\text { transmitting the infection to the } \\
\text { nurse's family. Stress also arises } \\
\text { due to age, level of education, } \\
\text { status marriage, experience and } \\
\text { position. Workload and } \\
\text { preparation which adequate. }\end{array}$ \\
\hline 6. & $\begin{array}{l}\text { Seoyon Yang, et al; } \\
\text { 2020; Korea } \\
\text { Selatan. }\end{array}$ & $\begin{array}{l}\text { Psychological impact of } \\
\text { COVID-19 on hospital } \\
\text { workers in nursing care } \\
\text { hospitals }\end{array}$ & $\begin{array}{l}\text { Quantitative } \\
\text { Cross-sectional }\end{array}$ & $\begin{array}{l}\text { Nurse } \\
(\mathrm{n}=54)\end{array}$ & $\begin{array}{l}\text { This study resulted in data that } \\
27 \% \text { of nurses showed symptom } \\
\text { worry. Nurse which work at } \\
\text { homesick have anxiety infecting } \\
\text { family and relatives as well as } \\
\text { alarge number of co- workers } \\
\text { infected result in workload tall } \\
\text { one. }\end{array}$ \\
\hline 7. & $\begin{array}{l}\text { Mohammed Al } \\
\text { Maqbali, et al; } \\
\text { 2020; Oman }\end{array}$ & $\begin{array}{l}\text { Psychological impact of the } \\
\text { coronavirus } 2019 \text { (COVID- } \\
\text { 19) pandemic on nurses }\end{array}$ & $\begin{array}{l}\text { Quantitative } \\
\text { Cross-sectional }\end{array}$ & $\begin{array}{l}\text { Nurse } \\
(\mathrm{n}=1130)\end{array}$ & $\begin{array}{l}\text { The results showed } 38.5 \% \text { of } \\
\text { nurses experience worry. A } \\
\text { statistically significant was higher }\end{array}$ \\
\hline
\end{tabular}




\begin{tabular}{|c|c|c|c|c|c|}
\hline & & & & & $\begin{array}{l}\text { in participants aged between } 22 \\
\text { and } 30 \text {, single individuals, those } \\
\text { with disease attendant, they which } \\
\text { own member family with guess } \\
\text { or confirmation COVID- } 19 \text {. }\end{array}$ \\
\hline 8. & $\begin{array}{l}\text { Enyew Mekonen, et } \\
\text { al; 2021; Ethiopia }\end{array}$ & $\begin{array}{l}\text { The Psycological Impact } \\
\text { of COVID-19 Outbreak } \\
\text { on Nurses Working in } \\
\text { The Northwest of Amhara } \\
\text { Regional State Referral } \\
\text { Hospital, Northwest } \\
\text { Ethiopia, }\end{array}$ & $\begin{array}{l}\text { Quantitative } \\
\text { Cross-sectional }\end{array}$ & $\begin{array}{l}\text { Nurse } \\
(n=302)\end{array}$ & $\begin{array}{l}\text { The results of the study stated that } \\
\text { the prevalence of anxiety was } \\
69.6 \% \text { / Factors that cause anxiety } \\
\text { this occur because no- } \\
\text { availability guidelines, afraid infect } \\
\text { family, and chronic disease } \\
\text { increases risk develop worry. } \\
\text { Workload, training, personal } \\
\text { protective equipment, having } \\
\text { children, being diagnosed with a } \\
\text { chronic disease, a history of mental } \\
\text { disorders, and living with } \\
\text { someone >60 years of age increase } \\
\text { risk psychology for nurses. }\end{array}$ \\
\hline 9. & $\begin{array}{l}\text { Hana M. Abu- } \\
\text { Snieneh, et al; 2020; } \\
\text { Saudi Arabia }\end{array}$ & $\begin{array}{l}\text { Psychological factors } \\
\text { associated with the spread } \\
\text { of Coronavirus disease } \\
2019 \text { (COVID-2019) } \\
\text { among nurses working in } \\
\text { health secators in Saudi } \\
\text { Arabia }\end{array}$ & $\begin{array}{l}\text { Quantitative } \\
\text { Cross-sectional }\end{array}$ & $\begin{array}{l}\text { Nurse } \\
(n=1265)\end{array}$ & $\begin{array}{l}\text { The results showed that age ( } 31- \\
40) \text { and workload were factors that } \\
\text { cause anxiety anddepression. }\end{array}$ \\
\hline 10. & $\begin{array}{l}\text { Qiuyang He, et al; } \\
\text { 2021; China }\end{array}$ & $\begin{array}{l}\text { Psychological effects of } \\
\text { the covid-19 outbreak on } \\
\text { nurses working in tertiary } \\
\text { women's and children's } \\
\text { hopitals from Sichuan, } \\
\text { China: A cross-sectional } \\
\text { study }\end{array}$ & $\begin{array}{l}\text { Quantitative } \\
\text { Cross-sectional }\end{array}$ & $\begin{array}{l}\text { Nurse } \\
(n=1971)\end{array}$ & $\begin{array}{l}\text { Nurses' anxiety was assessed on a } \\
\text { seven-item anxiety scale (GAD-7), } \\
\text { and General Self-Efficacy Scale } \\
\text { (GSES). Results study show that } \\
29.3 \% \text { nurse experience. Nurse } \\
\text { with years of service which long have } \\
\text { a high level of anxiety. In addition, } \\
\text { female nurses reported more severe } \\
\text { anxiety and lower self- efficacy than } \\
\text { male nurses. }\end{array}$ \\
\hline 12. & $\begin{array}{l}\text { Moluk } \\
\text { Pouralizadeh, et al; } \\
\text { 2020; Iran }\end{array}$ & $\begin{array}{l}\text { Anxiety and depression } \\
\text { and the related factors in } \\
\text { nurses of Guilan } \\
\text { University of Medical } \\
\text { Sciences hopitals during } \\
\text { COVID-19: A web-based } \\
\text { cross-sectional study }\end{array}$ & $\begin{array}{l}\text { Quantitative } \\
\text { Cross-sectional }\end{array}$ & $\begin{array}{l}\text { Nurse } \\
(\mathrm{n}=441)\end{array}$ & $\begin{array}{l}\text { The results showed that nurses in } \\
\text { hospitals in Iran experienced anxiety } \\
(38 \%) \text {. Worry to the nurse use } \\
\text { GAD-7 Studies. The disclose that } \\
\text { type sex woman and no have access } \\
\text { to private facilities which adequate } \\
\text { equipment protector is factors } \\
\text { associated with anxiety. }\end{array}$ \\
\hline 13. & $\begin{array}{l}\text { Mengyao Jiang, et } \\
\text { al; 2020; China }\end{array}$ & $\begin{array}{l}\text { The psychological effect } \\
\text { of } 2019 \text { coronoavirus } \\
\text { disease outbreak on } \\
\text { nurses living in Islamic } \\
\text { culture dominant region, } \\
\text { China }\end{array}$ & $\begin{array}{l}\text { Quantitative } \\
\text { Cross-sectional }\end{array}$ & $\begin{array}{l}\text { Nurse } \\
(n=1569)\end{array}$ & $\begin{array}{l}\text { The results showed that nurses who } \\
\text { were older and needed to take care of } \\
\text { children, worked in a designated } \\
\text { hospital for COVID-19, knowledge } \\
\text { desired related }\end{array}$ \\
\hline
\end{tabular}




\section{Discussion}

Anxiety is one of the psychological impacts that occur with a high prevalence rate experienced by nurses in various countries. This study tries to analyze the factors that influence nurses' anxiety during the COVID-19 pandemic. The results showed that many factors affect the anxiety of nurses. The age of nurses, especially those aged between 22 and 30 years, was the biggest predictor of anxiety. The reason is that lack of skills, knowledge and experience may have an influence on increasing the prevalence of anxiety. (Al Maqbali \& Al Khadhuri, 2021). The results of other studies stated that the average age of nurses was 30 years experiencing anxiety (Aliet al., 2021). Other research evidence suggests that younger nurses have less experience. Thus, they have a lower ability to handle crisis and disaster situations than older nurses who have more years of experience (Abu-Snieneh, 2021). In contrast to the research conducted in China where the population was nurses with special criteria (Islam), the results of the study stated that older people (>40 years) tended to experience severe anxiety. This happens possibly because old age is at risk ofexperiencing COVID-19 (Jiang et al., 2020).

The gender of nurses is also a factor that affects nurses' anxiety. Female nurses tend to experience severe anxiety. Women generally experience lower levels of self-efficacy than men so they are prone to anxiety, in the context of this pandemic, anxiety can be caused by the fear of contracting the virus due to direct exposure to patients, and the fear of transmitting the infection to their children (Simonetti, Valentinaet al., 2020; Pouralizadehet al., 2020). This statement is supported by other empirical evidence that female nurses report more severe anxiety than men. This may be related to differences in gender traits. Women are more concerned about inner experiences and self-perceptions, which makes them more fragile and sensitive, and more prone to anxiety (He et al., 2021). Agree with the results of this study, research in ICU nurses shows that female ICU nurses tend to experience severe anxiety (Heesakkers, Zegers, van Mol, \& van den Boogaard, 2021). However, the results of the research above are not in line with one of the studies conducted in Saudi Arabia (Aliet al., 2021). The study stated that male nurses experienced higher anxiety than women because female nurses had developed various personal and social mechanisms to deal with anxiety compared to men.

Marital status is a factor that affects anxiety. Nurses who are married and have children are associated with more severe psychological symptoms than those who are not (Aliet al., 2021). Married nurses can receive more support from their families, which lowers their risk of depression. Discrimination is also associated with psychological morbidity in nurses. During epidemics, health workers are branded as the source of infection. Discrimination and stigmatization increase the isolation of nurses, and potentially even have long-term effects on the psychological well-being of individuals (Hong, Ai, Xu, Wang, \& Chen, 2020).

However, this study is not in line with the statement that unmarried individuals have anxiety (Al Maqbali \& Al Khadhuri, 2021). This may be associated with the nurse having co- morbidities and living with family members. This may be because nurses are worried about the transmission of COVID-19 from the hospital and the consequences for the health of their families, so most nurses feel more anxious and the impact of an incident to be infected with this disease. Therefore, nurses in this study pay attention to their personal lives, especially those who have children and live with someone who is older, because this age group is more susceptible to infectious diseases. Lower education level factor. The importance of preparedness, either in terms of specialized training or previous experience working during a crisis was highlighted in previous studies (Hong et al., 2020). Being a frontline nurse seems to be a second predictor of anxiety, because of the nature of COVID-19 as a highly contagious 
disease, there has been a rapid increase in hospitalization rates, consequently increasing the workload of nurses. In addition, this may be because nurses are aware that COVID-19 survivors develop immunity, which can reduce the risk of relapse or reinfection (Al Maqbali \& Al Khadhuri, 2021). Nurses who work in hospitals designated for COVID care are also a factor of severe anxiety (Jiang et al., 2020). Our findings further suggest that working in a COVID-19 designated hospital is also a risk factor for anxiety due to the very high risk for psychological distress symptoms, and also some mental health and psychosocial considerations may be made during the outbreak (Pouralizadeh et al., 2020).

As for the relationship between personal protective equipment and nurses' anxiety, even though nurses have used personal protective equipment, it may still be dangerous for the patient to transmit infection, especially when managing the patient's condition, wiping sweat, or when undressing the patient (Lestari et al., 2021; Pouralizadeh et al., 2020). Therefore, it is important to train nurses on selfprotection and provide information on the characteristics of the pandemic, modes of transmission of the virus, diagnostic criteria, and clinical care. Furthermore, psychological counseling, with positive coping techniques, is very significant in reducing psychological burden

\section{Conclusion}

The factors that cause anxiety in nurses during the COVID-19 pandemic are based on a review of articles in categories based on the most common factors, including: gender (female nurse), work unit (hospital or room), risk perception, age, marital status, years of service, workload, information and training, availability of PPE, and level of education. It is important to conduct training programs related to COVID-19 for nurses to deal with the unknown nature of COVID-19, the uncertainty of the disease easily causes anxiety. Media as a source of information to build a positive image of nurses. The public's view of medical personnel is actually one of the nurse's social support. Hospitals should expend more efforts to ensure supplies of personal protective equipment, such as gloves, face masks

\section{Acknowledgements}

Researchers say many thanks to College of Health Sciences of Soetomo Hospital Foundation who has facilitated this research and not to forget to convey to all parties who have helped a lot in the completion of the preparation of this research journal.

\section{References}

Abu-Snieneh, H. M. (2021). Psychological factors associated with the spread of Coronavirus disease 2019 (COVID-19) among nurses working in health sectors in Saudi Arabia. Perspectives in Psychiatric Care, (October 2020), 1-11. https://doi.org/10.1111/ppc.12705

Al Maqbali, M., \& Al Khadhuri, J. (2021). Psychological impact of the coronavirus 2019 (COVID-19) pandemic on nurses. Japan Journal of Nursing Science, 2021(December 2020), 1-11. https://doi.org/10.1111/jjns.12417

Ali, S. A. A., Diab, S. S. E. M., \& Elmahallawy, E. K. (2021). Exploring the Psychological Stress, Anxiety Factors, and Coping Mechanisms of Critical Care Unit Nurses During the COVID-19 Outbreak in Saudi Arabia. Frontiers in Public Health, 9(November), 1-11. https://doi.org/10.3389/fpubh.2021.767517

Ali, S. K., Shah, J., \& Talib, Z. (2021). COVID-19 and mental well-being of nurses in a tertiary facility in Kenya. PloS One, 16(7), e0254074. https://doi.org/10.1371/journal.pone.0254074

Cai, H., Tu, B., Ma, J., Chen, L., Fu, L., Jiang, Y., \& Zhuang, Q. (2020). Psychological impact and coping strategies of frontline medical staff in Hunan between January and March 2020 during the outbreak of coronavirus disease 2019 (COVID) in Hubei, China. 
Medical Science Monitor, 26, 1-16. https://doi.org/10.12659/MSM.924171

Cho, M., Kim, O., Pang, Y., Kim, B., Jeong, H., Lee, J., ... Dan, H. (2021). Factors affecting frontline Korean nurses' mental health during the COVID-19 pandemic. International Nursing Review, 68(2), 256-265. https://doi.org/10.1111/inr.12679

He, Q., Ren, J., Wang, G., Zhang, J., Xiang, J., \& He, D. (2021). Psychological effects of the COVID-19 outbreak on nurses working in tertiary women's and children's hospitals from Sichuan, China: A cross-sectional study. International Journal of Disaster Risk Reduction, 58, 102188. https://doi.org/10.1016/j.ijdrr.2021.102188

Heesakkers, H., Zegers, M., van Mol, M. M. C., \& van den Boogaard, M. (2021). The impact of the first COVID-19 surge on the mental well-being of ICU nurses: A nationwide survey study. Intensive and Critical Care Nursing, 65, 103034. https://doi.org/10.1016/j.iccn.2021.103034

Hong, S., Ai, M., Xu, X., Wang, W., \& Chen, J. (2020). Since January 2020 Elsevier has created a COVID-19 resource centre with free information in English and Mandarin on the novel coronavirus COVID- 19. The COVID-19 resource centre is hosted on Elsevier Connect, the company's public news and information . (January).

Jiang, M., Li, S., She, D., Yan, F., Chung, Y. F., \& Han, L. (2020). The psychological effect of 2019 coronavirus disease outbreak on nurses living in Islamic culture dominant region, China. Archives of Psychiatric Nursing, 34(6), 513-519. https://doi.org/10.1016/j.apnu.2020.09.004

Lestari, I., Nursalam, N., \& Nastiti, A. A. (2021). Analysis of Factors Affecting Nurse Anxiety During Pandemic Covid-19. Psychiatry Nursing Journal (Jurnal Keperawatan Jiwa), 3(1), 15. https://doi.org/10.20473/pnj.v3i1.27468

Mekonen, Enyew; Shetie, Belayneh; Mukuneh, N. (2020). The Psychological Impact of COVID-19 Outbreak on Nurses Working in the Northwest of Amhara Regional State Referral Hospitals, Northwest Ethiopia. Psychology Research and Behavior Management, 13, 1353-1364. https://doi.org/10.1097/ADT.0000000000000269

Molero-Jurado, M. del M., Pérez-Fuentes, M. del C., Gázquez-Linares, J. J., \& Santillán García, A. (2021). Coping Strategies as a Mental Health Protection Factor of Spanish Nurses during COVID-19. International Journal of Environmental Research and Public Health, 18(23), 12748. https://doi.org/10.3390/ijerph182312748

Pouralizadeh, M., Bostani, Z., Maroufizadeh, S., Ghanbari, A., Khoshbakht, M., Alavi, S. A., \& Ashrafi, S. (2020). Anxiety and depression and the related factors in nurses of Guilan University of Medical Sciences hospitals during COVID-19: A web-based cross-sectional study. International Journal of Africa Nursing Sciences, 13(August), 100233. https://doi.org/10.1016/j.ijans.2020.100233

Salari, N., Khazaie, H., Hosseinian-Far, A., Khaledi-Paveh, B., Kazeminia, M., Mohammadi, M., ... Eskandari, S. (2020). The prevalence of stress, anxiety and depression within front-line healthcare workers caring for COVID-19 patients: a systematic review and meta-regression. Human Resources for Health, 18(1), 1-14. https://doi.org/10.1186/s12960-020-00544-1

Simonetti, Valentina; Durante, Angeal; Ambrosca, Rosella; Arcadi, Paola; Graziano, Glusi; Puccelarelli, Gianuluca; Simeona, Silvio; Vellone, Ercole; Alvaro, Rosaria; Cicollni, G. (2020). Anxiety sleep disorders and self-efficacy among nurses during COVID-19 pandemic: large cross-sectional study. Journal of Clinical Nursing, 30, 1360-1371. https://doi.org/10.1111/jocn.15685

Zhang, J., Wu, W., Zhao, X., \& Zhang, W. (2019). Recommended psychological crisis intervention response to the 2019 novel coronavirus pneumonia outbreak in China : a model of.

Zhang, Y., Wei, L., Li, H., Pan, Y., Wang, J., Li, Q., ... Wei, H. (2020). The Psychological Change Process of Frontline Nurses Caring for Patients with COVID-19 during Its Outbreak. Issues in Mental Health Nursing, 0(0), 525-530. https://doi.org/10.1080/01612840.2020.1752865 